\title{
Impacts of urbanization on the distribution of heavy metals in soils along the Huangpu River, the drinking water source for Shanghai
}

\author{
Yang Bai ${ }^{1,2} \cdot$ Min Wang $^{2} \cdot$ Chi Peng $^{1}$ (D) Juha M. Alatalo ${ }^{3}$
}

Received: 24 May 2015 / Accepted: 3 November 2015 / Published online: 12 November 2015

(C) Springer-Verlag Berlin Heidelberg 2015

\begin{abstract}
We investigated the horizontal and vertical distribution of heavy metals $(\mathrm{Hg}, \mathrm{Pb}, \mathrm{Zn}, \mathrm{Cu}, \mathrm{Cd}, \mathrm{As}, \mathrm{Ni}$, and $\mathrm{Cr})$ in soils in the water source protection zone for Shanghai to study the origins of these metals, their connections with urbanization, and their potential risk posed on the ecosystem. Determination of metal concentrations in 50 topsoil samples and nine soil profiles indicated that $\mathrm{Hg}, \mathrm{Pb}, \mathrm{Zn}$, and $\mathrm{Cu}$ were present in significantly higher concentrations in topsoil than in deep soil layers. The spatial distributions of $\mathrm{Hg}, \mathrm{Pb}, \mathrm{Zn}$, and $\mathrm{Cu}$ and contamination hotspots for these metals in the study area were similar to those near heavy industries and urban built-up areas. Emissions from automobiles resulted in increased soil concentrations of $\mathrm{Cu}, \mathrm{Pb}$, and $\mathrm{Zn}$ along roadsides, while high concentrations of $\mathrm{Hg}$ in the soil resulted from recent atmospheric deposition. Calculation of the potential
\end{abstract}

Responsible editor: Philippe Garrigues

Summary We investigated the spatial and vertical distribution of heavy metals in soil in the Shanghai water supply area to determine the sources of contamination and the impacts of urbanization.

Electronic supplementary material The online version of this article (doi:10.1007/s11356-015-5745-3) contains supplementary material, which is available to authorized users.

Chi Peng

cpeng@live.com; chipeng@rcees.ac.cn

1 State Key Laboratory of Urban and Regional Ecology, Research Center for Eco-environmental Sciences, Chinese Academy of Sciences, Beijing 100085, People's Republic of China

2 Shanghai Academy of Environmental Sciences, Shanghai 200233, People's Republic of China

3 Department of Biological and Environmental Sciences, College of Arts and Sciences, Qatar University, P.O. Box 2713, Doha, Qatar ecological risk indicated that the integrative risk of these heavy metals in most areas was low, but a few sites surrounding high density of factories showed moderate risks.

Keywords Risk assessment · Land use - Vertical distribution · Soil profile $\cdot$ Suburban area $\cdot$ Spatial analysis $\cdot$ Heavy metals Potential ecological risk

\section{Introduction}

To fulfill the resource needs of rapid industrialization and urbanization, heavy metals have been mined from the Earth's crust directly or with associated minerals. Since these metals are minor components of fossil fuels and industrial products, they tend to accumulate in the biosphere, resulting in increased heavy metal content in soil, water, and the atmosphere (Ajmone-Marsan and Biasioli 2010). Heavy metals in the environment are non-biodegradable and subject to bioaccumulation (Wong et al. 2006). At natural background levels, most heavy metals are beneficial to natural biota but become a threat when they occur at high concentrations (Okuda et al. 2008; Wong et al. 2006). In China, many cities and counties are facing the challenge of heavy metal pollution, particularly of urban and agricultural soils (Cheng et al. 2014; Wei and Yang 2010).

Urban areas are the geographical center of metal emissions. Road networks and industrial plants are the two main sources of heavy metal emissions in urbanized and peri-urban areas (Chen et al. 2010; Dayani and Mohammadi 2010; Wong et al. 2006). Previous studies have shown that population density, traffic volume, industrialized land use, and timing of urbanization are positively correlated with metal concentrations in surrounding soils (Argyraki and Kelepertzis 2014; Guney 
et al. 2010; Peng et al. 2013). Soils in suburban and rural areas surrounding cities can be affected by atmospheric deposition of heavy metals originating from the city (Wei and Yang 2010; Wu et al. 2010). Due to high persistence of metals in soils, analyses can provide information on historical metal contamination, e.g., associated with ancient human activities and former industrial activities (Chen et al. 2005; Chen et al. 2010; Xia et al. 2011; Zhang et al. 2005). Knowledge on the distribution of heavy metals in soil is therefore essential for addressing the connections between metal accumulation and anthropogenic influences.

Heavy metals in soils are the result of both natural and anthropogenic processes. To determine the relative contributions of the two sources, previous studies have estimated natural background values, measured in remote pristine soils or deep soil layers (Biasioli et al. 2006). Widespread atmospheric deposition of heavy metals originates from anthropogenic sources, but physical disturbance of upper soil layers can affect the reliability of background value measurements (Wong et al. 2006). It should be noted that background concentrations of heavy metals cannot be presented as single values but as a range of values that vary according to the geological and mineralogical characteristics of the parent material (Reimann and Garrett 2005). For these reasons, the single ratio of metal concentration to average background value is not suitable for determining the influence of anthropogenic sources on heavy metal accumulation (Reimann and Caritat 2000). It is therefore necessary to undertake statistical analysis and geographical mapping in order to study the impacts of anthropogenic activities on heavy metal accumulation in soils.

The metropolitan Shanghai, which has a total population of over 23 million, is facing rapid industrialization and urbanization. Previous works had reported considerably increases of heavy metal contents in the urban soil and industrialized suburban soil of the city (Chen et al. 2012; Shi et al. 2008). The protection zones for centralized drinking water sources are essential for the health of residents and are located away from the urban areas. However, the rapid urban sprawl of Shanghai has extended the sphere of urban influence, which may be threatening the safety of drinking water sources. For this reason, we investigated the horizontal and vertical distribution of heavy metals in soils along the upper reaches of the Huangpu River, the water source for metropolitan Shanghai. Our aims were (1) to determine the factors that cause and affect heavy metal accumulation in this area. (2) to examine the impacts of urbanization and industrialization on heavy metal accumulation in the area, and (3) to identify the potential ecological risks of heavy metal accumulation in the soils.

\section{Method and analysis}

\section{Sampling}

Dianshan Lake is regarded as the source of the upper Huangpu River, which runs through rural and suburban Shanghai and finally into the downtown area of the city (total length $75 \mathrm{~km}$; Fig. 1). Since this river represents the major water source for Shanghai, many water supply points are located along its upper reaches, such as the Changqiao waterworks, the Minhang waterworks, the second Qingpu waterworks, and the second Songjiang waterworks. To protect drinking water quality, the government has delineated a water source protection zone along the upper reaches of Huangpu River in which heavily polluting enterprises are prohibited. However, hundreds of factories already exist in this area and urban Shanghai has since expanded into the protection zone (Fig. 2).

To investigate the spatial distribution of heavy metals in the area, we divided the drinking water source protection zone into $5 \mathrm{~km} \times 5 \mathrm{~km}$ grids and randomly selected sites in each grid to obtain a total of 50 soil samples (Fig. 1). Each sample comprised five pooled subsamples of topsoil $(0-20 \mathrm{~cm})$ taken within $100 \mathrm{~m}^{2}$ of the sampling site. The land use at the sampling sites was classified during the sampling process according to potential metal emission sources present as rural $(n=33)$, roadsides $(n=10)$, villages $(n=4)$, and forest $(n=3)$. The rural sites were further subdivided into two categories, namely farmland sites $(n=14)$ and countryside sites $(n=19)$, with the latter having at least one industrial factory located within $500 \mathrm{~m}$.

Soil profile samples were taken from six randomly selected rural sites (three farmland sites and three countryside sites) to represent the vertical distribution of heavy metals in soils influenced/not influenced by contamination from industrial activities. The groundwater in the area is at around $1 \mathrm{~m}$ depth. Each soil profile was divided into five layers, 0-20, 20-40, 40-60, 60-80, and $80-100 \mathrm{~cm}$, and five samples were taken from each, resulting in a total of 30 soil profile samples. In addition, three soil profiles (each from the 0-10-, 10-20-, and 20$40-\mathrm{cm}$ layer) were taken from the forest sites to represent soil only under the influence of atmospheric deposition.

\section{Chemical analysis}

The soil samples were air-dried and then milled to pass through a sieve with $0.1 \mathrm{~mm}$ mesh. The concentrations of $\mathrm{Cd}, \mathrm{Pb}, \mathrm{Zn}, \mathrm{Cu}, \mathrm{As}, \mathrm{Ni}$, and $\mathrm{Cr}$ in the samples were determined according to USEPA standard methods (6010C-2007): The milled soils were digested using a four-acid mixture of $\mathrm{HCl}$, $\mathrm{HNO}_{3}, \mathrm{HF}$, and $\mathrm{HClO}_{4}$, and the metal concentrations in the digested extracts were determined by ICP-AES (Optima 2100 DV, PerkinElmer, USA). For analyses of $\mathrm{Hg}$, the soils were digested in an acid mixture of $\mathrm{H}_{2} \mathrm{SO}_{4}, \mathrm{HNO}_{3}$, and $\mathrm{K}_{2} \mathrm{Cr}_{2} \mathrm{O}_{7}$, 


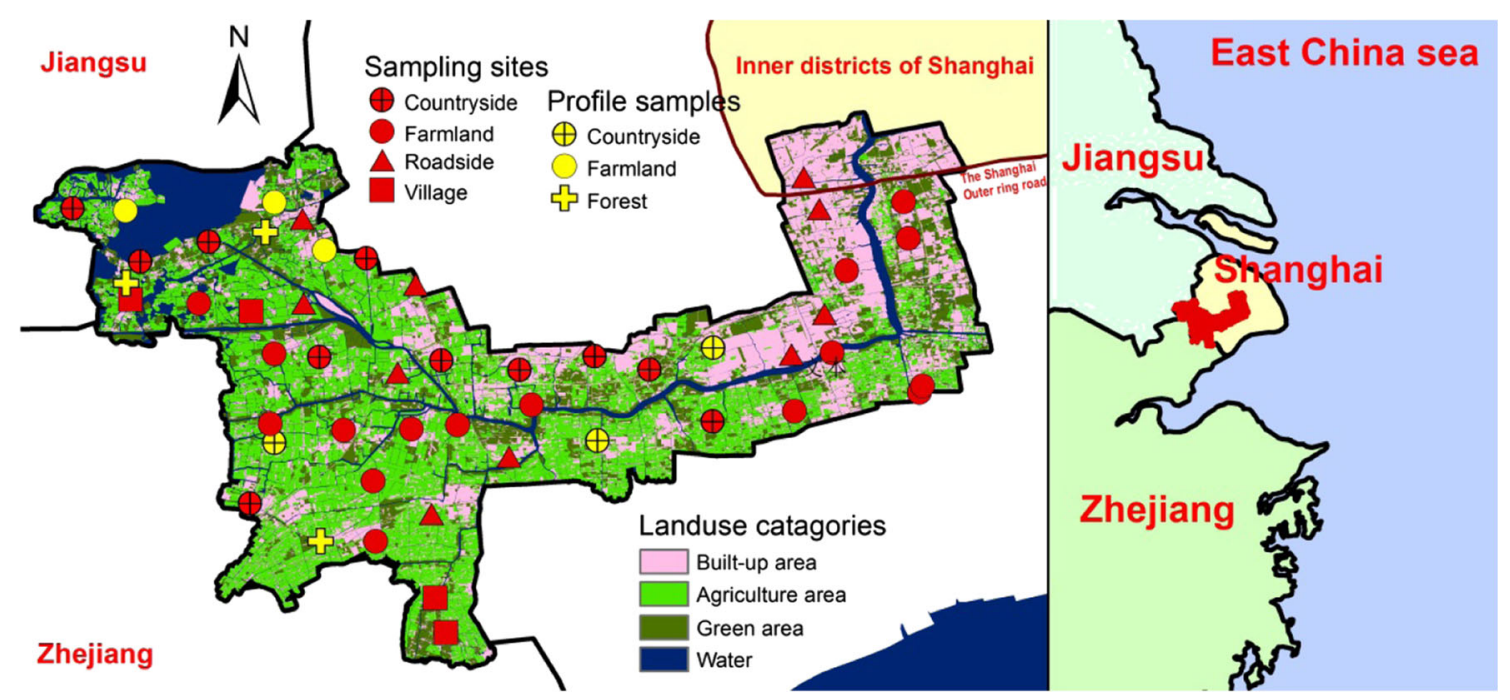

Fig. 1 The sampling sites and land use along the upper reaches of Huangpu River, the drinking water source protection zone of Shanghai

and the extracts were analyzed using a Mercury Automated Analyzer (MA-3000, Nippon Instruments Corporation, Japan). National standard reference soil (Center for Certified Reference Materials, China), duplicate samples, and blank samples were analyzed simultaneously in each array of assays. The recovery rate was $85-115 \%$ for the heavy metals in the standard reference materials. Soil $\mathrm{pH}$ was measured in a soil/ deionized water suspension of 1:2.5 $(w / v)$. Soil water content was determined by the gravimetric method and soil bulk density by drying a soil core of known volume. Soil organic matter (SOM) was determined using the potassium dichromate oxidation procedure.

\section{Statistical analysis}

Statistical analyses of the data were conducted in SPSS (version 18.0), including hierarchical cluster analysis, analysis of variance (ANOVA) analysis, the KolmogorovSmirnov test (K-S test), and regression analysis. Before cluster analysis and ANOVA, the metal concentration data were log-transformed to obtain an approximation of normal distribution. The calculation of metal leaching potential was performed in Excel 2010, while ArcGIS 10.1 software was used for geographical mapping and Getis-ord Gi* analysis.
Fig. 2 Spatial distributions of factories and constructed area along upper reaches of the Huangpu River

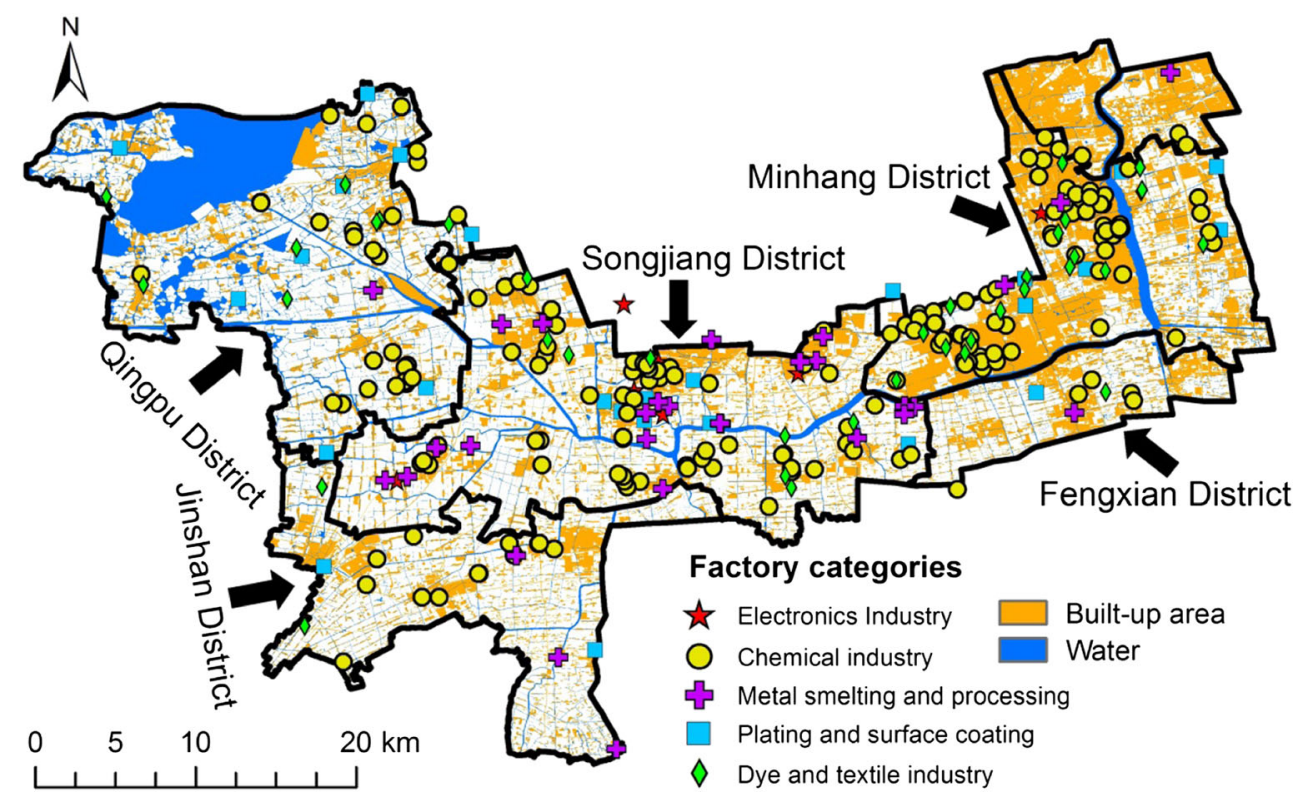




\section{Calculation of potential ecological risk}

The Hakanson potential ecological risk index (RI) was used widely for a comprehensive assessment of the harmful effects of heavy metals in soil (Qu et al. 2014; Yuan et al. 2014; Zhou et al. 2014). The risk index was calculated using the following equation (Hakanson 1980):

$\mathrm{RI}=\sum_{i}^{n} E_{r}^{i}=\sum_{i}^{n} T_{r}^{i} \times \frac{C_{t}^{i}}{C_{f}^{i}}$

where $C_{t}^{i}$ denotes the concentrations of the $i$ th metal species in soil and $C_{f}^{i}$ the reference concentration of the $i$ th metal species in pristine soil, in the current study, taken as the mean metal concentrations in the deep soil layers $(80-100 \mathrm{~cm}) . T_{r}^{i}$ is the toxic response factor for the $i$ th metal species, which was recommended as 40 for $\mathrm{Hg}, 30$ for $\mathrm{Cd}, 10$ for $\mathrm{As}, 5$ for $\mathrm{Pb}, \mathrm{Cu}$, and $\mathrm{Ni}, 2$ for $\mathrm{Cr}$, and 1 for $\mathrm{Zn}$ (Qu et al. 2014). $E_{r}^{i}$ represents the individual potential ecological risk index for the $i$ th metal species. RI is the potential ecological risk index for multiple heavy metals in soil. The $E_{r}^{i}$ can be grouped into four levels, and the $\mathrm{RI}$ is classified into five grades of risks (Table S2).

\section{Results and discussions}

\section{Metal concentrations and comparisons}

Heavy metal concentrations in topsoil along the upper reaches of the Huangpu River, a major water supply of metropolitan Shanghai, are shown in Table 1. The mean concentration of $\mathrm{Hg}, \mathrm{Pb}, \mathrm{Zn}, \mathrm{Cu}, \mathrm{Cd}, \mathrm{As}, \mathrm{Ni}$, and $\mathrm{Cr}$ in the soils was $0.14,21.5$, $87.7,32.3,0.19,6.1,30.9$, and $66.1 \mathrm{mg} / \mathrm{kg}$, respectively. The statistical distributions of $\mathrm{Hg}, \mathrm{Pb}, \mathrm{Zn}$, and $\mathrm{Cu}$ showed higher values of skewness and kurtosis than those of $\mathrm{Cd}, \mathrm{As}, \mathrm{Ni}$, and
$\mathrm{Cr}$ (Table 1). This suggests that the natural concentrations of $\mathrm{Hg}, \mathrm{Pb}, \mathrm{Zn}$, and $\mathrm{Cu}$ in a few samples were significantly elevated by human activities. The metal concentrations observed were comparable to those reported for suburban soils in Beijing (HU et al. 2006) but lower than those observed in the industry-based suburban area of Wuxi (Zhao et al. 2007). Compared with two water source protection zones, in Beijing and the Pearl River delta, the Shanghai water source protection zone had significantly higher concentrations in soil of all heavy metals except As (Table 2). These differences in metal concentrations between regions may be partly caused by the types of parent soil material, especially changes in median values. However, anthropogenic causes cannot be ignored, since the urban sprawl of Shanghai had reached the water source protection area for the city.

Table 1 shows the average background levels of heavy metals in Shanghai soils according to the National Environmental Monitoring Center of China. The mean and median concentrations of $\mathrm{Hg}, \mathrm{Zn}, \mathrm{Cu}, \mathrm{Cd}, \mathrm{Ni}$, and $\mathrm{Cr}$ in deep soil layers of our study area were comparable to the average background values for Shanghai, but those of $\mathrm{Pb}$ and As were lower (Table 2). Differences in the mean and median concentrations of $\mathrm{Cd}, \mathrm{As}, \mathrm{Ni}$, and $\mathrm{Cr}$ between topsoil and deep soil layers in the study area were minor, suggesting that these metals originated from parent rock and were less affected by modern industrial activities. However, the large differences in mean concentrations of $\mathrm{Hg}, \mathrm{Pb}, \mathrm{Zn}$, and $\mathrm{Cu}$ between surface soils and deep soils indicate anthropogenic emissions of those metals in the upper reaches of the Huangpu River (Table 2). Hierarchical cluster analysis to improve understanding of heavy metal accumulation patterns revealed that the eight metals studied here were grouped into two major clusters in topsoil, namely $[\mathrm{Pb}+\mathrm{Zn}+\mathrm{Cu}+\mathrm{Hg}]$ and $[\mathrm{Cr}+\mathrm{Ni}+\mathrm{As}+\mathrm{Cd}]$ (Fig. 3). This grouping suggests the heavy metals in this area have two major accumulation patterns. In the first group, $[\mathrm{Pb}$

Table 1 Statistical parameters for metal concentrations in topsoil along the upper reaches of the Huangpu River

\begin{tabular}{|c|c|c|c|c|c|c|c|c|c|c|c|c|c|}
\hline & & $\begin{array}{l}\mathrm{Hg} \\
(\mathrm{mg} / \mathrm{kg})\end{array}$ & $\begin{array}{l}\mathrm{Pb} \\
(\mathrm{mg} / \mathrm{kg})\end{array}$ & $\begin{array}{l}\mathrm{Zn} \\
(\mathrm{mg} / \mathrm{kg})\end{array}$ & $\begin{array}{l}\mathrm{Cu} \\
(\mathrm{mg} / \mathrm{kg})\end{array}$ & $\begin{array}{l}\mathrm{Cd} \\
(\mathrm{mg} / \mathrm{kg})\end{array}$ & $\begin{array}{l}\mathrm{As} \\
(\mathrm{mg} / \mathrm{kg})\end{array}$ & $\begin{array}{l}\mathrm{Ni} \\
(\mathrm{mg} / \mathrm{kg})\end{array}$ & $\begin{array}{l}\mathrm{Cr} \\
(\mathrm{mg} / \mathrm{kg})\end{array}$ & $\begin{array}{l}\theta_{w} \\
\left(1_{\text {water }} / 1_{\text {soil }}\right)\end{array}$ & $\mathrm{pH}$ & $\begin{array}{l}\rho \\
(\mathrm{kg} / \mathrm{l})\end{array}$ & $\begin{array}{l}\text { SOM } \\
(\%)\end{array}$ \\
\hline \multicolumn{2}{|l|}{ Mean } & 0.14 & 21.5 & 87.7 & 32.3 & 0.186 & 6.1 & 30.9 & 66.1 & 24.48 & 7.47 & 1.27 & 3.01 \\
\hline \multicolumn{2}{|c|}{ Std. deviation } & 0.09 & 8.65 & 23.31 & 9.24 & 0.068 & 1.9 & 4.37 & 10.07 & 9.25 & 0.85 & 0.16 & 1.06 \\
\hline \multicolumn{2}{|l|}{ Minimum } & 0.04 & 9.36 & 52.6 & 13.9 & 0.050 & 3.6 & 22.5 & 47.7 & 6.53 & 4.15 & 0.99 & 0.36 \\
\hline \multirow[t]{4}{*}{ Percentiles } & $25 \%$ & 0.07 & 16.38 & 75.08 & 27 & 0.150 & 4.8 & 28.15 & 58.33 & 16.73 & 7.4 & 1.17 & 2.4 \\
\hline & $50 \%$ & 0.12 & 18.75 & 83.15 & 30.8 & 0.180 & 5.6 & 30.65 & 66.6 & 23.15 & 7.69 & 1.26 & 2.88 \\
\hline & $75 \%$ & 0.16 & 24.8 & 95.18 & 37.78 & 0.223 & 6.8 & 33.95 & 71.73 & 32.26 & 7.92 & 1.37 & 3.57 \\
\hline & $90 \%$ & 0.26 & 33.18 & 115.7 & 45.26 & 0.279 & 9.9 & 36.76 & 82.59 & 37.94 & 8.05 & 1.56 & 4.55 \\
\hline \multicolumn{2}{|l|}{ Maximum } & 0.48 & 53 & 177 & 70.4 & 0.340 & 10.8 & 41.8 & 86.7 & 46.43 & 8.29 & 1.61 & 6.02 \\
\hline \multicolumn{2}{|l|}{ Skewness } & 1.79 & 1.73 & 1.69 & 1.42 & 0.25 & 1.04 & 0.14 & 0.08 & 0.26 & -2.57 & 0.48 & 0.47 \\
\hline \multicolumn{2}{|l|}{ Kurtosis } & 3.58 & 3.55 & 4.11 & 4.92 & 0.28 & 0.31 & -0.12 & -0.52 & -0.68 & 6.72 & -0.34 & 1.89 \\
\hline \multicolumn{2}{|c|}{$\begin{array}{l}\text { Backgrounds } \\
\quad \text { (CNEMC 1990) }\end{array}$} & 0.043 & 21 & 74.7 & 24.4 & 0.133 & 9 & 29.9 & 63.4 & & & & \\
\hline
\end{tabular}




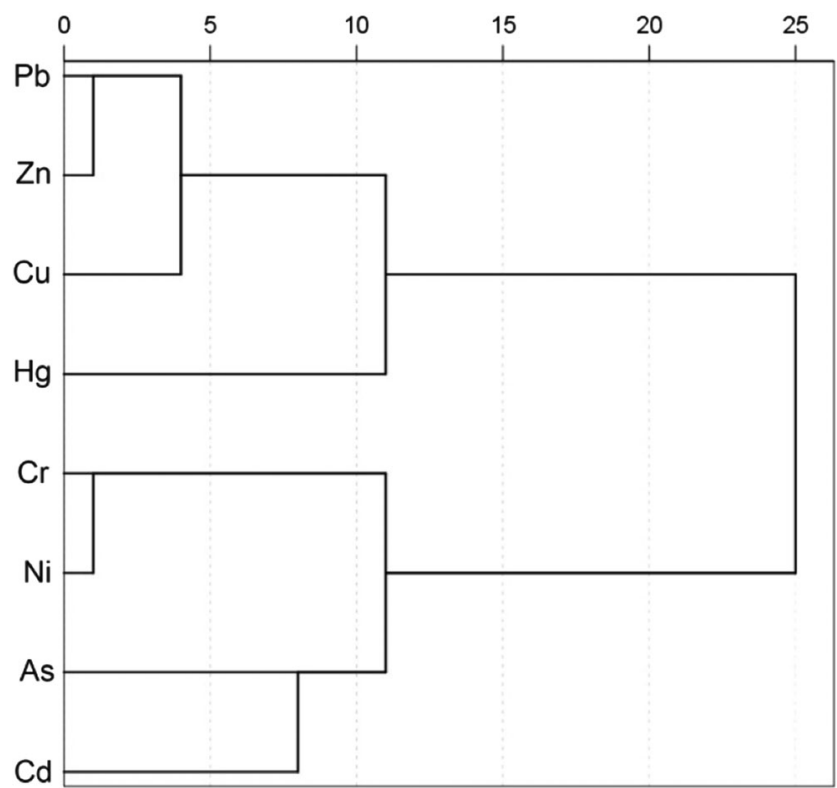

Fig. 3 Dendrogram of heavy metals in soils along the upper reaches of Huangpu River using hierarchical cluster analysis

$+\mathrm{Zn}+\mathrm{Cu}+\mathrm{Hg}]$, concentrations in topsoil were higher than in deep soil layers, indicating exterior inputs from anthropogenic sources. On the other hand, the topsoil concentrations of the second group, $[\mathrm{Cr}+\mathrm{Ni}+\mathrm{As}+\mathrm{Cd}]$, showed normal distributions and the differences between topsoil and deep soil were minor, suggesting that the concentrations of these metals were not influenced by human activities. The sources, distribution, and ecological risks of $\mathrm{Hg}, \mathrm{Pb}, \mathrm{Zn}$, and $\mathrm{Cu}$ in this area should be further investigated.

\section{Impacts of urbanization on metal distribution}

The Huangpu River flows across rural, suburban, and urban areas of Shanghai. Previous studies have reported on contamination levels of heavy metals in the soils around the middle and lower reaches of this river (Table 2). Compared to the results of the present study, these studies have indicated that the soil concentrations of $\mathrm{Hg}, \mathrm{Pb}, \mathrm{Zn}, \mathrm{Cu}, \mathrm{Cd}$, and $\mathrm{Cr}$ had increased to double and six times in the urban areas of Shanghai (Cheng et al. 2014; Shi et al. 2008). Minor changes in Ni concentrations were noted in soils along the uppermiddle-lower reaches of the Huangpu River. Chen et al. (2012) reported concentrations of $\mathrm{Pb}, \mathrm{Zn}, \mathrm{Cu}$, and $\mathrm{Cr}$ in the soils of Baoshan District, a heavily industrialized suburban area of Shanghai near the lower reaches of the Huangpu River that were significantly higher than those found in the present study. Overall, soil metal concentrations vary dramatically along the upper-middle-lower reaches of the Huangpu River, suggesting that urbanization and industrialization are the main causes of metal contamination in the city. We found that the soils along the upper reaches of the Huangpu River 
had the lowest mean concentrations of heavy metals of all regions in the city. However, the impacts of urbanization and industrial activities on heavy metal distribution inside this region provide cause for concern, because relatively high concentrations in even a few samples can threaten water quality.

Figure 4 shows the spatial distribution of $\mathrm{Hg}, \mathrm{Pb}, \mathrm{Zn}, \mathrm{Cu}$, and $\mathrm{Cd}$ measured in soils along the upper reaches of Huangpu River. The size of the graphic symbols used in the diagram is proportional to metal concentration within different percentiles. Getis-ord Gi* analysis was used to mark the hotspots of metal contamination, by means of studying the spatial autocorrelation of sampling sites (Fig. 4). Each hotspot indicates a sampling site surrounded by several highly polluted
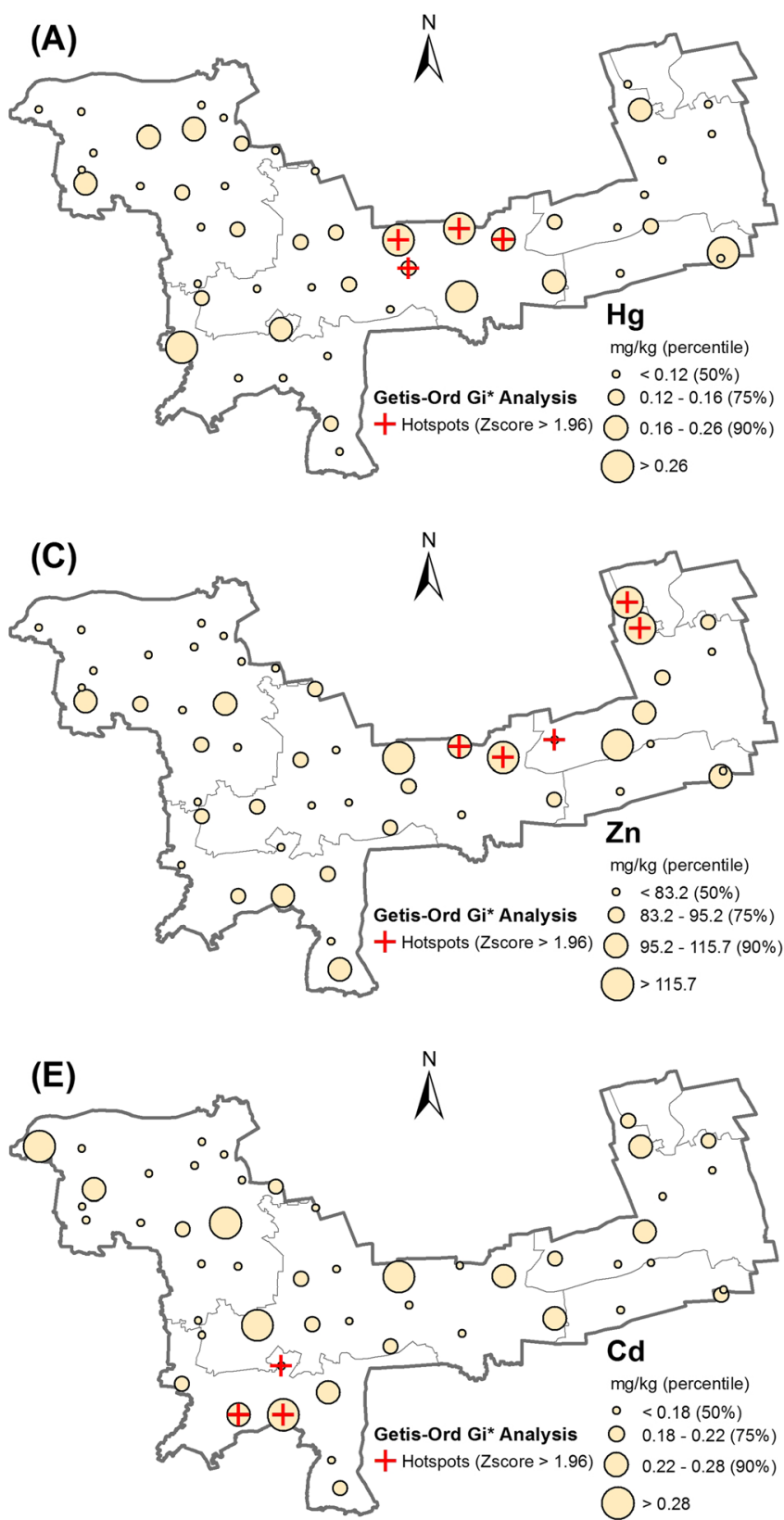

sampling sites that were aggregated to form an area of high metal contamination. Spatial differences in parent soil materials may have caused natural fluctuations in metal concentrations in the soils, but the highlighted hotspots and the sampling sites with high metal concentrations (i.e., with the largest symbols in Fig. 4) are probably associated with human activities. Hotspots and sites with high concentrations of $\mathrm{Hg}, \mathrm{Pb}$, $\mathrm{Zn}$, and $\mathrm{Cu}$ tended to aggregate in west Minhang district and east Songjiang district (Fig. 2), while the high Cd concentration areas were randomly distributed along the upper reaches of the Huangpu River (Fig. 4e).

Industrial activities and urban transportation were important emission sources of heavy metals. Figure 2 shows the
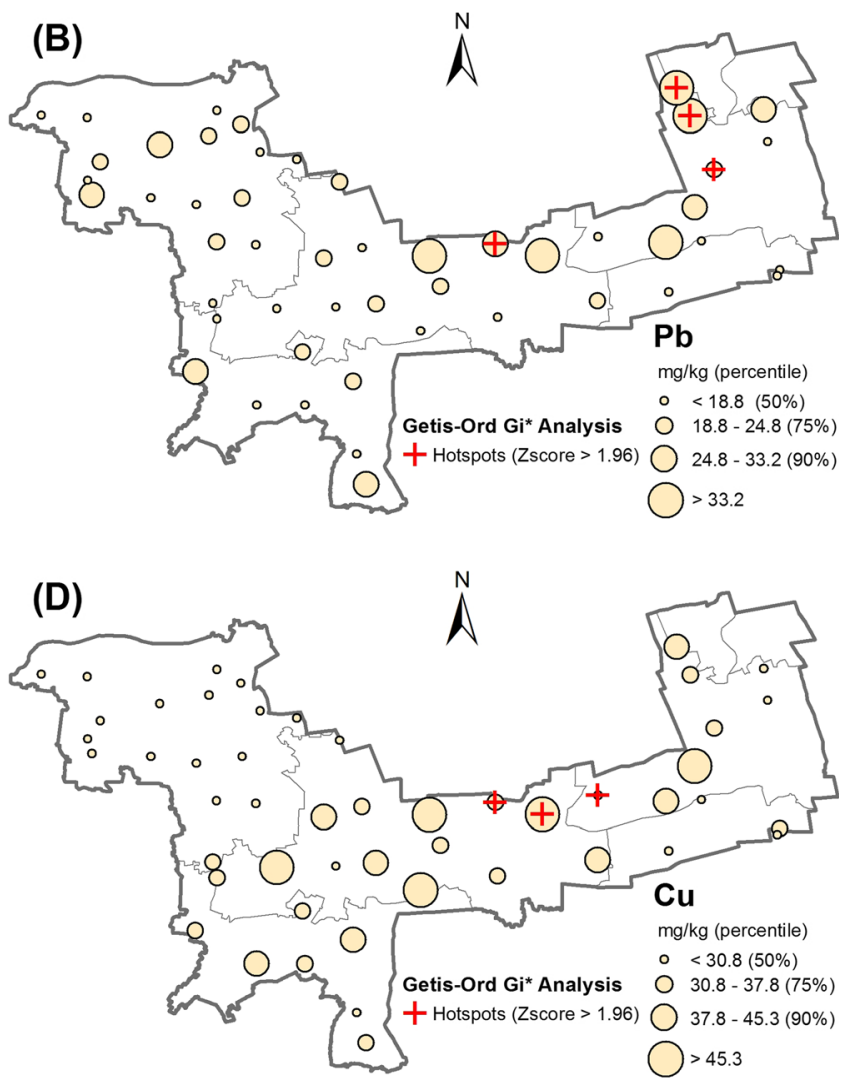

Fig. 4 Spatial distributions of $\mathrm{Hg}, \mathrm{Pb}, \mathrm{Zn}, \mathrm{Cu}$, and $\mathrm{Cd}$ in the soils along upper reaches of the Huangpu River 
Fig. 5 Concentrations of heavy metals in soils under different land utilizations

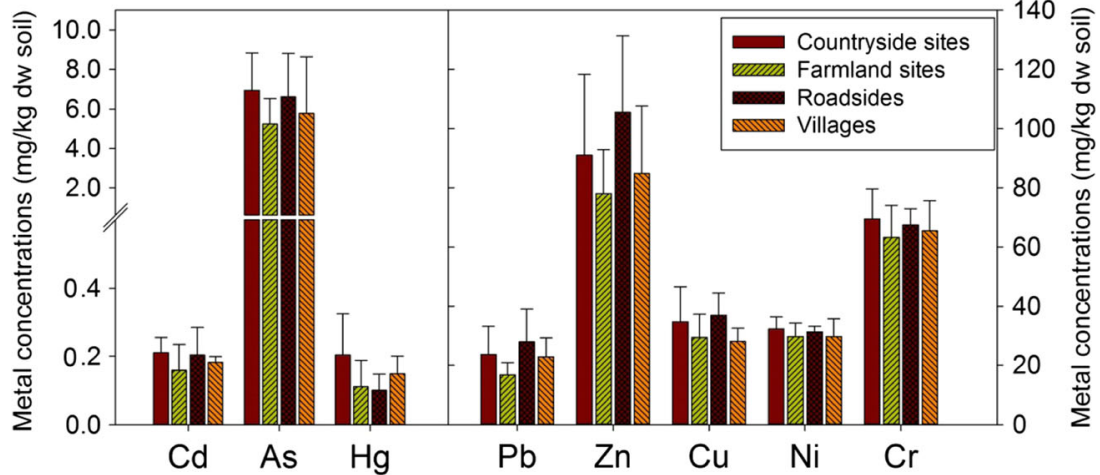

spatial distributions of heavy industries and urban built-up areas along the upper reaches of the Huangpu River. The density of built-up area can be used as an indicator of the extent of urbanization and transportation. The factories in the study area were preliminarily classified into five categories: electronics, chemicals, metal smelting and processing, plating and surface coating, and dye and textiles. The spatial distribution of $\mathrm{Hg}, \mathrm{Pb}, \mathrm{Zn}$, and $\mathrm{Cu}$ in the soils appeared to show some similarities to the positions of industries and built-up areas (Figs. 2 and 4). A high density of factories and high levels of urbanization were mainly found in west Minhang and east Songjiang districts, in which most hotspots and high contamination sites of $\mathrm{Hg}, \mathrm{Pb}, \mathrm{Zn}$, and $\mathrm{Cu}$ also occurred.

\section{Impacts of land utilization}

We classified the sampling sites into four land use types according to the distribution of metal emission sources, namely farmland sites, countryside sites, roadsides, and villages. Differences in mean concentrations of the eight metals studied were noted in these four land use areas (Fig. 5). The highest mean concentrations of $\mathrm{Cu}, \mathrm{Pb}$, and $\mathrm{Zn}$ were found in roadside soils $(37.7 \mathrm{mg} / \mathrm{kg}$ for $\mathrm{Cu}, 27.9 \mathrm{mg} / \mathrm{kg}$ for $\mathrm{Pb}$, and $105.5 \mathrm{mg} / \mathrm{kg}$ for $\mathrm{Zn}$ ), while the corresponding mean concentrations of $\mathrm{Cu}$, $\mathrm{Pb}$, and $\mathrm{Zn}$ in farmland soils were significantly lower (ANOVA: $p<0.05$ ), 29.3, 16.7, and $78.0 \mathrm{mg} / \mathrm{kg}$, respectively. This suggests that automobile traffic is a significant source of these metals. Wear on brakes, tires, and other vehicle components can release large quantities of $\mathrm{Cu}$ and $\mathrm{Zn}$ into the environment (Johansson et al. 2009), while the $\mathrm{Pb}$ in roadside soils may be a legacy of burning leaded fuel (Biasioli et al. 2006).

The mean concentrations of $\mathrm{Hg}, \mathrm{Pb}, \mathrm{Cd}$, and As were $0.201,23.6,0.211$, and $6.96 \mathrm{mg} / \mathrm{kg}$, respectively, in the countryside soils and $0.111,16.8,0.159$, and $5.2 \mathrm{mg} / \mathrm{kg}$, respectively, in the farmland soils (Fig. 5). ANOVA showed that the differences were significant $(p<0.05)$. We distinguished two categories (countryside countryside farmland sites) in the rural soils sampled, which were and were not, respectively, under the direct influence of industry activities. Wastewater and gas discharges from industries may enter surrounding soils through atmospheric deposition and/or irrigation, thus increasing soil metal concentrations. For example, chemical and metallurgy industries are responsible for high emissions of $\mathrm{Hg}$, $\mathrm{Pb}, \mathrm{Cd}$, and $\mathrm{As}$ into the surrounding environment by these routes (Ajmone-Marsan and Biasioli 2010; Cazier et al. 2011). The $\mathrm{Cd}$ and $\mathrm{Pb}$ found in the Huangpu River soils studied here may have originated from plating and coating industries. The electronics industry is also responsible for metal emissions (Ajmone-Marsan and Biasioli 2010).

\section{Vertical distribution of heavy metals in the soils}

The concentrations of heavy metals in different soil layers are commonly used to investigate their accumulation history and leaching processes. Figure 6 shows the vertical distribution of heavy metals in the soil profiles from the three countryside

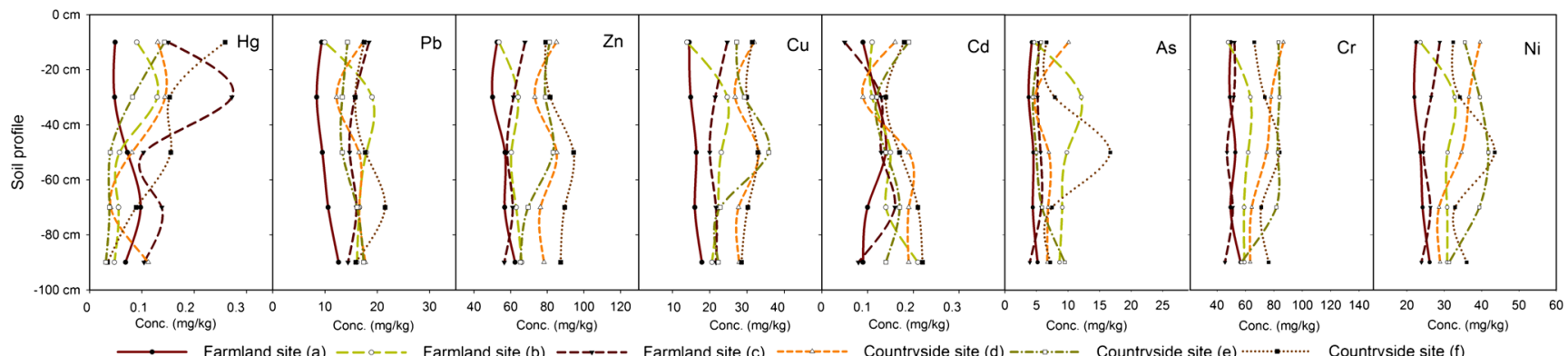

Fig. 6 Profiles of heavy metals in rural soils along the upper reaches of Huangpu River 


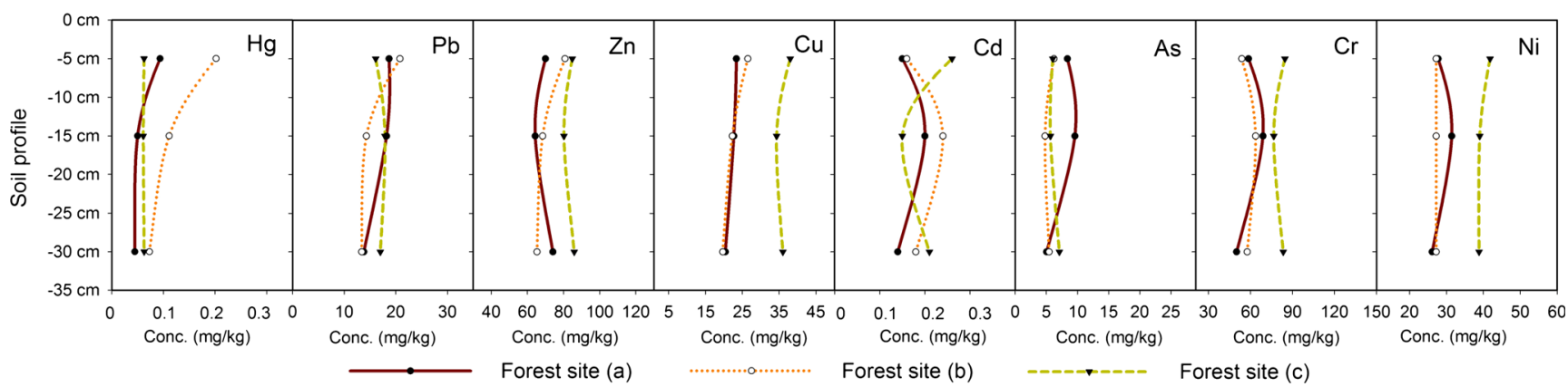

Fig. 7 Profiles of heavy metals in forest soils along the upper reaches of Huangpu River

sites near industries and the three control farmland sites that were beyond the direct influence of industrial activities. The metal concentrations in most soil layers were slightly higher at the three countryside sites than at the farmland sites but fluctuated with depth in the soil. There was no clear difference in metal concentrations between the top and bottom soil layers except for $\mathrm{Hg}$, the concentrations of which showed a decreasing gradient with depth. This indicates accumulation of $\mathrm{Hg}$ in surface soil as a result of recent urbanization and industrialization. At one farmland site (site (c) in Fig. 6), the concentrations of $\mathrm{Hg}, \mathrm{Pb}, \mathrm{Zn}, \mathrm{Cu}, \mathrm{As}, \mathrm{Cr}$, and $\mathrm{Ni}$ in the $20-40-\mathrm{cm}$ soil layer were considerably higher than those in the $0-20-\mathrm{cm}$ soil layer, suggesting that the surface soil at this site might have been recently transported there from elsewhere for agricultural purposes. At one countryside site (site (f) in Fig. 6), the concentrations of $\mathrm{Zn}, \mathrm{Cu}, \mathrm{As}$, and $\mathrm{Ni}$ showed abnormal increases at $40-60 \mathrm{~cm}$ depth, indicating a buried soil layer with historical contamination. Therefore, the major factors affecting metal concentrations in soil layers were fluctuations in background values and past physical disturbance. The impacts of soil solute leaching on metal concentrations in deep soil layers were probably minor, due to the strong adsorption of heavy metals to soil particles (Chen et al. 2009).

Forest soil profiles were sampled at remote sites (Fig. 7), far from industries and urban traffic, where atmospheric deposition was the most likely path by which heavy metals would have entered the soil (as opposed to farmland, which was under direct human interventions such as irrigation). The mean concentration of $\mathrm{Hg}, \mathrm{Pb}, \mathrm{Zn}, \mathrm{Cu}, \mathrm{Cd}, \mathrm{As}, \mathrm{Ni}$, and $\mathrm{Cr}$ in the 20-40-cm layer of forest soils was $0.06,14.7,75.1,25.4$, $0.18,5.86,30.7$, and $63.7 \mathrm{mg} / \mathrm{kg}$, respectively. These were similar to the concentrations in the $80-100-\mathrm{cm}$ layer at farmland sites but lower than those in the deep soil layer in urban Shanghai (Table 2), indicating the natural background of heavy metals in this region. No significant differences in $\mathrm{Pb}, \mathrm{Zn}, \mathrm{Cu}, \mathrm{Cd}$, As, $\mathrm{Cr}$, and $\mathrm{Ni}$ concentration were found between the topsoil and deeper soil layers at the forest sites (ANOVA: $p>0.05$ ). A high $\mathrm{Hg}$ content was observed in the first (upper) soil layer of forest land and decreased rapidly with increasing soil depth, which suggests that atmospheric deposition was the major input of $\mathrm{Hg}$ in this region.

Fig. 8 Spatial distribution of the potential ecological risk in soils along the upper reaches of Huangpu River

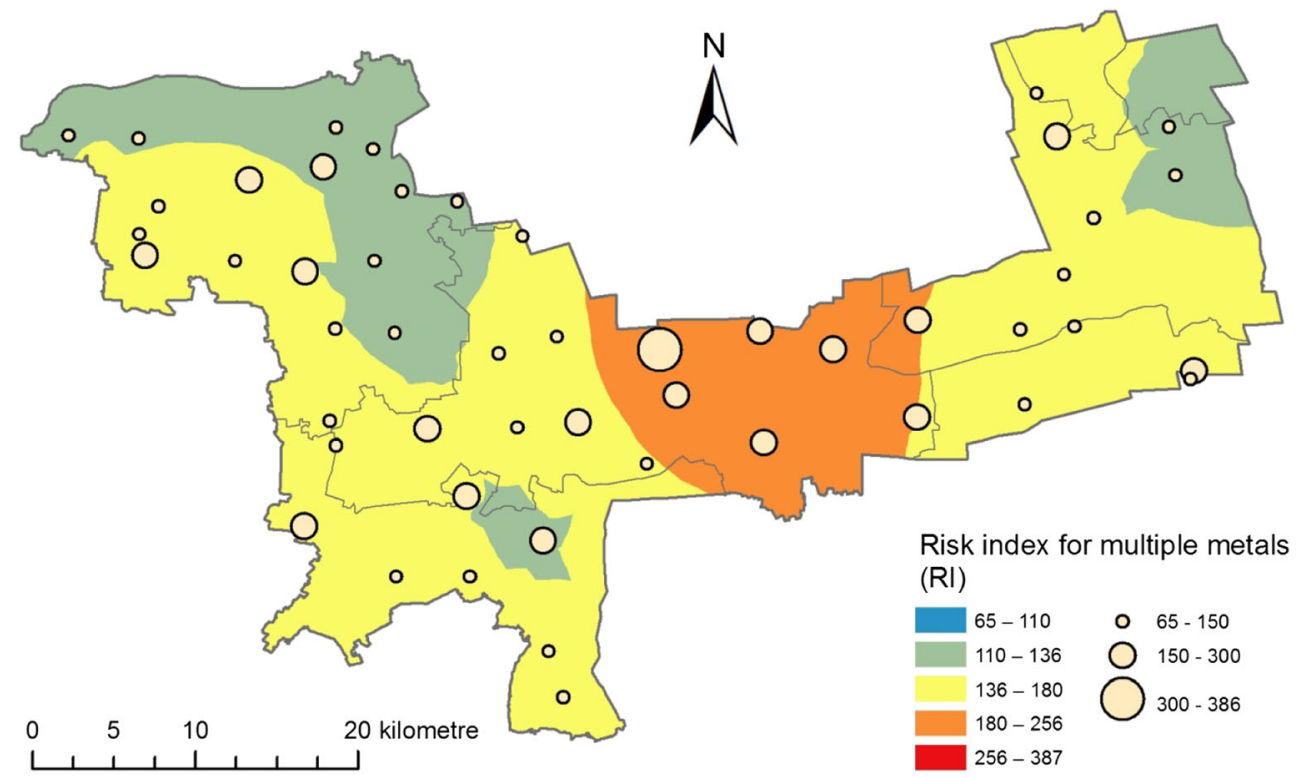




\section{Potential ecological risk assessments}

The potential ecological risk index for individual metal species $\left(E_{r}^{i}\right)$ and multiple metals (RI) are summarized in Table S1, the mean of which follows the gradient of $\mathrm{RI}>\mathrm{Hg}>\mathrm{Cd}>\mathrm{As}$ $>\mathrm{Cu}>\mathrm{Pb}>\mathrm{Ni}>\mathrm{Cr}>\mathrm{Zn}$. According to the classification of $E_{r}^{i}$, only $\mathrm{Hg}$ and $\mathrm{Cd}$ had their concentrations exceeding the moderate risk level (Table S2). $\mathrm{Hg}$ in $6 \%$ and $30 \%$ of the sampling sites had high and considerable risks, respectively, while the $E_{r}^{i}$ of $\mathrm{Pb}, \mathrm{Zn}, \mathrm{Cu}, \mathrm{As}, \mathrm{Ni}$, and $\mathrm{Cr}$ in all the samples showed low risk levels. These results suggested higher ecological risks for $\mathrm{Hg}$ and $\mathrm{Cd}$ than the other metals, especially $\mathrm{Hg}$ should be of concern in terms of the high ecological hazard it may pose to the surface soil in the water source protection area.

The RI value is the integrative risk index of multiple contaminants, ranged from 65.5 to 386.5 with a mean value of 151.6 in the study area (Table S1). The threshold values of RI between the low, moderate, and considerable risk levels are 150 and 300 , respectively, based on which the sampling sites are classified into three groups, namely low risk (64\%), moderate risk (34\%), and considerable risk (2\%) (Fig. 8). The east Songjiang district is marked as a hotspot area of RI, in which high density of factories can be found (Fig. 8). Meanwhile, the west Minhang district with the highest level of urbanization and $\mathrm{Pb} / \mathrm{Zn}$ contents however shows relatively lower RI. The spatial distribution of RI is similar to the distribution of $\mathrm{Hg}$ (Fig. 4), because the $E_{r}^{i}$ of $\mathrm{Hg}$ contribute on average $55 \%$ of the risk index to RI in the study area (Fig. S1). The differences of $E_{r}^{i}$ between $\mathrm{Hg}$ and the other metals mainly resulted from their toxic response factors $\left(T_{r}^{i}\right)$ and abnormally high concentration at a few sampling sites (Zhou et al. 2014). Therefore, RI reflects the risk of high toxic metals that are released by industrial activities in this region.

\section{Conclusions}

This analysis of horizontal and vertical distributions of heavy metals in soils along the upper reaches of the Huangpu River (the drinking water source for Shanghai) revealed significantly elevated concentrations of $\mathrm{Hg}, \mathrm{Pb}, \mathrm{Zn}$, and $\mathrm{Cu}$ in topsoil, while the concentrations of $\mathrm{As}, \mathrm{Ni}$, and $\mathrm{Cr}$ were close to natural background levels. Spatial distributions and $\mathrm{Hg}, \mathrm{Pb}, \mathrm{Zn}$, and $\mathrm{Cu}$ hotspots in the soils coincided with the location of heavy industries and built-up areas. Emissions from factories have resulted in increased levels of $\mathrm{Hg}, \mathrm{Pb}, \mathrm{Cd}$, and $\mathrm{As}$ in surrounding countryside soils. Elevated concentrations of $\mathrm{Cu}, \mathrm{Pb}$, and $\mathrm{Zn}$ were also found in roadside soils. Examination of the metal distributions in soil profiles suggested that the elevated $\mathrm{Hg}$ concentrations were probably the result of recent urbanization and industrialization in the surrounding areas. On calculating the potential ecological risks, we concluded that the presence of heavy metals in soils in the study area poses moderate risk to the east Songjiang district, which is associated with the industrial activities in this region.

Acknowledgments We gratefully acknowledge financial support provided by the National Natural Science Foundation of China (Grant No. 41401588, 41501580).

\section{References}

Ajmone-Marsan F, Biasioli M (2010) Trace elements in soils of urban areas. Water Air Soil Pollut 213:121-143

Argyraki A, Kelepertzis E (2014) Urban soil geochemistry in Athens, Greece: the importance of local geology in controlling the distribution of potentially harmful trace elements. Sci Total Environ 482483:366-377

Biasioli M, Barberis R, Ajmone-Marsan F (2006) The influence of a large city on some soil properties and metals content. Sci Total Environ 356:154-164

Cazier F, Dewaele D, Delbende A, Nouali H, Garçon G, Verdin A, Courcot D, Bouhsina S, Shirali P (2011) Sampling analysis and characterization of particles in the atmosphere of rural, urban and industrial areas. Procedia Environ Sci 4:218-227

Chen T, Zheng Y, Lei M, Huang Z, Wu H, Chen H, Fan K, Yu K, Wu X, Tian Q (2005) Assessment of heavy metal pollution in surface soils of urban parks in Beijing, China. Chemosphere 60:542-551

Chen W, Wu L, Chang AC, Hou Z (2009) Assessing the effect of longterm crop cultivation on distribution of $\mathrm{Cd}$ in the root zone. Ecol Model 220:1836-1843

Chen X, Xia X, Zhao Y, Zhang P (2010) Heavy metal concentrations in roadside soils and correlation with urban traffic in Beijing, China. $\mathrm{J}$ Hazard Mater 181:640-646

Chen YY, Wang J, Gao W, Sun XJ, Xu SY (2012) Comprehensive analysis of heavy metals in soils from Baoshan District, Shanghai: a heavily industrialized area in China. Environ Earth Sci 67:23312343

Cheng H, Li M, Zhao C, Li K, Peng M, Qin A, Cheng X (2014) Overview of trace metals in the urban soil of 31 metropolises in China. J Geochem Explor 139:31-52

CNEMC, 1990. The backgrounds of soil environment in China. China Environment Science Press (in Chinese), Beijing

Dayani M, Mohammadi J (2010) Geostatistical assessment of Pb, Zn and $\mathrm{Cd}$ contamination in near-surface soils of the urban-mining transitional region of Isfahan, Iran. Pedosphere 20:568-577

Guney M, Onay TT, Copty NK (2010) Impact of overland traffic on heavy metal levels in highway dust and soils of Istanbul, Turkey. Environ Monit Assess 164:101-110

Hakanson L (1980) An ecological risk index for aquatic pollution control. A sedimentological approach. Water Res 14:975-1001

Hu KL, Zhang FR, Li H, Huang F, Li BG (2006) Spatial patterns of soil heavy metals in urban-rural transition zone of Beijing. Pedosphere

Hu Y, Liu X, Bai J, Shih K, Zeng EY, Cheng H (2013) Assessing heavy metal pollution in the surface soils of a region that had undergone three decades of intense industrialization and urbanization. Environ Sci Pollut Res 20:6150-6159

Johansson C, Norman M, Burman L (2009) Road traffic emission factors for heavy metals. Atmos Environ 43:4681-4688

Luo W, Lu Y, Zhang Y, Fu W, Wang B, Jiao W, Wang G, Tong X, Giesy JP (2010) Watershed-scale assessment of arsenic and metal contamination in the surface soils surrounding Miyun Reservoir, Beijing, China. J Environ Manag 91:2599-2607 
Okuda T, Katsuno M, Naoi D, Nakao S, Tanaka S, He K, Ma Y, Lei Y, Jia Y (2008) Trends in hazardous trace metal concentrations in aerosols collected in Beijing, China from 2001 to 2006. Chemosphere 72: 917-924

Peng C, Ouyang Z, Wang M, Chen W, Li X, Crittenden JC (2013) Assessing the combined risks of PAHs and metals in urban soils by urbanization indicators. Environ Pollut 178:426-432

Qu MK, Li WD, Zhang CR (2014) Spatial distribution and uncertainty assessment of potential ecological risks of heavy metals in soil using sequential Gaussian simulation. Hum Ecol Risk Assess 20:764-778

Reimann C, Caritat P (2000) Intrinsic flaws of element enrichment factors (EFs) in environmental geochemistry. Environ Sci Technol 34: 5084-5091

Reimann C, Garrett RG (2005) Geochemical background - concept and reality. Sci Total Environ 350:12-27

Shi G, Chen Z, Xu S, Zhang J, Wang L, Bi C, Teng J (2008) Potentially toxic metal contamination of urban soils and roadside dust in Shanghai, China. Environ Pollut 156:251-260

Wei B, Yang L (2010) A review of heavy metal contaminations in urban soils, urban road dusts and agricultural soils from China. Microchem J 94:99-107

Wong CSC, Li X, Thornton I (2006) Urban environmental geochemistry of trace metals. Environ Pollut 142:1-16
Wu S, Xia X, Lin C, Chen X, Zhou C (2010) Levels of arsenic and heavy metals in the rural soils of Beijing and their changes over the last two decades (1985-2008). J Hazard Mater 179:860-868

Xia X, Chen X, Liu R, Liu H (2011) Heavy metals in urban soils with various types of land use in Beijing, China. J Hazard Mater 186: 2043-2050

Yuan GL, Sun TH, Han P, Li J, Lang XX (2014) Source identification and ecological risk assessment of heavy metals in topsoil using environmental geochemical mapping: typical urban renewal area in Beijing, China. J Geochem Explor 136:40-47

Zhang G, Yang F, Zhao Y, Zhao W, Yang J, Gong Z (2005) Historical change of heavy metals in urban soils of Nanjing, China during the past 20 centuries. Environ Int 31:913-919

Zhao YF, Shi XZ, Huang B, Yu DS, Wang HJ, Sun WX, ÖBoern I, BlombÄCk K (2007) Spatial distribution of heavy metals in agricultural soils of an industry-based peri-urban area in Wuxi, China. Pedosphere 17:44-51

Zhou L, Yang B, Xue N, Li F, Seip HM, Cong X, Yan Y, Liu B, Han B, Li $H$ (2014) Ecological risks and potential sources of heavy metals in agricultural soils from Huanghuai Plain, China. Environ Sci Pollut Res 21:1360-1369 